\title{
SOCIAL NETWORKING SITES USAGE AND SUBJECTIVE WELL-BEING IN COVID-19 PANDEMIC CONDITIONS
}

In Happiness And Contemporary Society : Conference Proceedings Volume (Lviv, March, 20-21, 2021). Lviv: SPOLOM, 2021. P. 277-279. https://doi.org/10.31108/7.2021.62

ISBN 978-966-919-697-2

ЯГІЯЄВ ІЛЛЯ, НОВОСЕЛЬСЬКА АЛіна

\section{ВИКОРИСТАННЯ СОЦАЛЬНИХ МЕРЕЖ ТА СУБ'ЄКТИВНЕ БЛАГОПОЛУЧЧЯ \\ В УМОВАХ ПАНДЕМIÏ COVID-19}

// Щастя та сучасне суспільство : збірник матеріалів міжнародної наукової конференції (Львів, 20-21 березня 2021 р.). - Львів : СПОЛОМ, 2021. С. 277-279. https://doi.org/10.31108/7.2021.62

ISBN 978-966-919-697-2 
https://doi.org/10.31108/7.2021.62

YAGIYAYEV Illya

PhD in Psychology, Faculty of Psychology,

Taras Shevchenko National University of Kyiv (Kyiv, Ukraine)

NOVOSELSKA Alina

Student of Faculty of Psychology,

Taras Shevchenko National University of Kyiv (Kyiv, Ukraine)

\section{SOCIAL NETWORKING SITES USAGE AND SUBJECTIVE WELL-BEING IN COVID-19 PANDEMIC CONDITIONS}

The relevance of the topic is related to the psychosocial consequences of the COVID19 pandemic. The aim is to study the subjective well-being during the beginning of the pandemic and introduction of the quarantine measures and their connection to social media activity. The methods employed in the present study include various types of questionnaires, namely the Positive and Negative Affect Schedule (PANAS) (Watson, Clark \& Tellegen, 1988), the Satisfaction With Life Scale (SWLS) (Diener, Emmnos, Larsen, \& Griffin, 1985), the General Self-Efficacy Scale (Schwarzer \& Jerusalem, 1995), and an original questionnaire developed to study the impact of the pandemic and the respondents' understanding and perceptions of it. The findings of the quantitative analysis show that the subjective well-being during the pandemic is connected to the use of social media, life satisfaction, health risks assessments and economic consequences, leisure time and the level of self-efficacy. A qualitative analysis indicates that at the beginning of the COVID-19 pandemic in Ukraine the negative predictions of the consequences of both the pandemic and the implemented quarantine measures prevail among the subjects. A longitudinal study during one month has found a reduction in health concerns, and respondents began to assess the threat to their health and economic consequences of the coronavirus pandemic as less serious than at the beginning. Thus, it can be concluded that from a short-term perspective the negative affect, especially the levels of fear and anxiety, decreased, whereas the level of the positive affect did not change.

Keywords: psychological well-being, subjective well-being, pandemic, life satisfaction, social media, conspiracy theories, COVID-19.

ЯГІЯЕВ Ілля

кандидат психологічних наук

Київський національний університет імені Тараса Шевченка (Київ, Украӥна)

НОВОСЕЛЬСЬКА АЛіна

студентка факультуту психології,

Київський національний університет імені Тараса Шевченка (Київ, Украӥна)

\section{ВИКОРИСТАННЯ СОЦАЛЬНИХ МЕРЕЖ ТА СУБ'СКТИВНЕ БЛАГОПОЛУЧЧЯ В УМОВАХ ПАНДЕМІЇ COVID-19}

Актуальність теми пов'язана $з$ психологічними наслідками пандемії COVID19. Через пандемію COVID-19 у багатьох країнах світу було впроваджено карантин, що часто $є$ неприємним досвідом для людей. Розлука з близькими, як i 
потреба постійно знаходитися поряд 3 ними, втрата можливості вільного пересування, загальна непевність та нудьга можуть 3 часом спричиняти вельми негативні наслідки. Повідомлялося про самогубства, спалахи гніву та судові позови після введення карантину під час попередніх спалахів інфекційних захворювань.

Іншим відомим чинником, пов'язаним зі сприйманням пандемії, $\epsilon$ використання соціальних мереж. Емпірично доведено існування зв'язку між використанням соціальних мережам та психологічним благополуччям (SampasaKanyinga Hugues et al., 2015, Utz \& Breuer, 2017). В умовах соціальної, економічної та епідеміологічної кризи соціальні мережі можуть швидко поширювати як надійну та перевірену інформацію, так і дезінформацію (Taylor, 2019; Tang, Bie, Park, \& Zhi, 2018).

Метою було дослідження суб'єктивного благополуччя на початку пандемії i запровадження карантинних заходів, та їхнього зв’язку з активністю у соціальних мережах. Використовувалися шкала позитивного та негативного афекту (Watson, Clark \& Tellegen, 1988), шкала задоволеності життям (SWLS) (Diener, Emmnos, Larsen, \& Griffin, 1985), шкала загальної самоефективності (Schwarzer \& Jerusalem, 1995), авторська анкета сприймання пандемії та уявлень про неї.

У межах нашого дослідження було виявлено та охарактеризовано вплив пандеміі на благополуччя людини.

Вибірка формувалася весною 2020 року. Рекрутинг відбувався у соціальних мережах facebook та Instagram. Для збору даних застосовувалася платформа 1ka.si. Всі досліджувані заповнювали методики анонімно i добровільно. Загальна кількість досліджуваних, які відповіли на всі питання батареї методик, склала 1339 осіб, з них було видалено відповіді тих, хто вказав свій вік як 9, 14, 16 та 212. Кінцева кількість досліджуваних склала 1332 особи, 3 них 218 чоловіків, 1109 жінок, а також 5 осіб визначили свою гендерну належність як "іншу”.

Було виявлено, що на психологічне благополуччя людей під час пандемії впливають такі чинники: використання соціальних мереж, оцінка загрози для здоров'я та економічних наслідків, проведення вільного часу та рівень самоефективності.

Відповідно до очікувань, оцінка наслідків для здоров'я має помірний зв'язок 3 конспірологічними теоріями, як, наприклад, те, що коронавірус небезпечніший, ніж про нього кажуть, а від людей приховують правду про великі масштаби епідемії $(\mathrm{r}=0,31, \mathrm{p}=0.0000 * * *)$. Також чим більшим $\epsilon$ рівень тривоги стосовно наслідків для власного здоров'я, тим вищим $є$ негативний афект ( $=0,21, \mathrm{p}=$ $\left.0.0000^{* * *}\right)$, однак оцінка наслідків для здоров'я близьких ще сильніше кореляцію 3 негативним афектом $(\mathrm{r}=0,26, \mathrm{p}=0.0000 * * *)$.

Оцінка економічних наслідків епідемії сильно корелює 3 оцінкою впливу пандемії на буденне життя після ii завершення $(\mathrm{r}=0,47-0,51, \mathrm{p}=0.0000 * * *), 3$ оцінкою впливу пандемії на здоров'я ( $\mathrm{r}=0,25-0.35, \mathrm{p}=0.0000 * * *)$, а також помірний зв'язок $з$ деякими конспірологічними твердженнями, особливо 3 тим, що коронавірус небезпечніший, ніж про нього кажуть, а від людей приховують правду про великі масштаби епідемії $(\mathrm{r}=0,21, \mathrm{p}=0.0000 * * *)$. Невеликий зв'язок є між прогнозуванням економічних наслідків та задоволеністю життям ( $\mathrm{r}=0,13, \mathrm{p}=$ $\left.0.0000^{* * *}\right)$, що свідчить про негативні настрої у цій сфері. Удвічі більший зв'язок між оцінкою економічних наслідків та негативного афекту $(\mathrm{r}=0,20-0.25, \mathrm{p}=$ $0.0000 * * *)$. 
Відповідно до гіпотези, оцінка наслідків для здоров'я має помірний зв'язок 3 конспірологічними теоріями. Було отримано дані про те, що чим більше досліджувані використовують соціальні мережі на пошук інформації про коронавірус, тим більше це пов'язано з оцінкою наслідків пандемії ( $\mathrm{r}=0,2, \mathrm{p}=$ $\left.0.0000^{* * *}\right)$. Вiра в конспірологічні теорії була пов'язана з використанням Facebook $\left(\mathrm{r}=0,28, \mathrm{p}=0.0000^{* * *}\right)$, а особливо 3 думкою, що під приводом коронавірусу влада бажає обмежити свободу людей.

Зв'язок за способом проведення часу на карантині також має різницю у залежності від того, чим переважно займаються досліджувані. Так, перегляд онлайн курсів та читання книг має помірний зв'язок із позитивним афектом респондентів $\left(\mathrm{r}=0,21-0.23, \mathrm{p}=0.0000^{* * *}\right)$, у той час коли гортання стрічки в соціальних мережах - із негативним $\left(\mathrm{r}=0,25, \mathrm{p}=0.0000^{* * *}\right)$, а особливо 3 такими почуттями, як пригнічення, зляканість, невпевненість, занепокоєння та тривога. Також перегляд курсів, фільмів та читання книг позитивно меншою мірою, але має зв'язок з почуттям самоефективності $\left(\mathrm{r}=0,16, \mathrm{p}=0.0000^{* * *}\right)$, а гортання стрічки негативно $(\mathrm{r}=-0,12, \mathrm{p}=0.0000 * * *)$.

Стосовно задоволеності життям та соціальними мережами зв'язку встановлено не було, однак чим більше вони використовуються для саморозвитку, тим вищим є позитивний афект $\left(\mathrm{r}=0,25, \mathrm{p}=0.0000^{* * *}\right)$, а чим більше для прокрастинації $\left(\mathrm{r}=-0,24, \mathrm{p}=0.0000^{* * *}\right)$, тим меншим $€$ показник позитивного афекту і вищим показник негативного афекту $\left(\mathrm{r}=0,22, \mathrm{p}=0.0000^{* * *}\right)$. Було встановлено помірний зв'язок між використанням соціальних мереж для отримання інформації про вірус та негативним афектом $\left(\mathrm{r}=0,28, \mathrm{p}=0.0000^{* * *}\right)$, a також наступними емоціями: зляканість, занепокоєність та тривожність.

Самоефективність має значущий зв'язок 3 позитивним афектом досліджуваних $\left(\mathrm{r}=0,47, \mathrm{p}=0.0000^{* * *}\right)$, помірний - із задоволеністю життям $(\mathrm{r}=$ $\left.0,34, \mathrm{p}=0.0000^{* * *}\right)$ та помірну зворотню кореляцію 3 негативним афектом $(\mathrm{r}=$ $\left.0,31, \mathrm{p}=0.0000^{* * *}\right)$. Таким чином, можна сказати, що віра в ефективність власних дій значною мірою пов'язана не лише 3 поведінкою, а й 3 суб'єктивним благополуччям людини.

\section{ЛIТЕРАТУРА}

1. Diener, E., Emmons, R. A., Larsen, R. J., \& Griffin, S. The Satisfaction With Life Scale. Journal of Personality Assessment, 49(1), 71-75. - 1985.

2. Sampasa-Kanyinga Hugues. Cyberpsychology, Behavior, and Social Networking / Sampasa-Kanyinga Hugues, Lewis Rosamund F. // Monthly. - 2015.

3. Schwarzer, R., \& Jerusalem, M. Generalized Self-Efficacy scale. - 1995.

4. Tang, Bie, Park, \& Zhi. Social media and outbreaks of emerging infectious diseases: A systematic review of literature. -2018.

5. Taylor, S. The psychology of pandemics: Preparing for the next global outbreak of infectious disease. Cambridge Scholars Publishing. - 2019.

6. Utz, S., \& Breuer, J. (2017). The relationship between use of social network sites, online social support, and well-being: Results from a six-wave longitudinal study. Journal of Media Psychology: Theories, Methods, and Applications, 29(3), 115-125.

7. Watson, D., Clark, L. A., \& Tellegen, A. Development and Validation of Brief Measures of Positive and Negative Affect: The PANAS Scales. Journal of Personality and Social Psychology, 54, 1063-1070. - 1998. 